\title{
UJI COBA DENGAN MENGGUNAKAN TIANG PEMBANTU DAN PERBAIKAN MEKANIK PADA DRUM PENGGULUNG PENGANGKUTAN BIBIT DENGAN SISTEM KABEL LAYANG
}

\section{(Trial test of seedling tranportation by skyline cable system using movable tower and mechanical improvement on pulling drum)}

\author{
Oleh/By: \\ Wesman Endom ${ }^{1}$
}

'Pusat Litbang Hasil Hutan, Jl. Gunung Batu No. 5 Bogor Tlp/Fax: 86333413-8633378

Diterima 30 Mei 2008; disetujui 25 Juni 2008

\begin{abstract}
National programme of forest and land rebabilitation efforts is addressed to recovery of degraded forest and land. Seedling transportation on heavy terrain faced big problems. An anticipation of seedling transportation is required to provide and good quality seedling.

This trial test was done to get an effective and, efficient tool to be used for seedling transportation on heavy terrain. Preliminary test was done in Carita Banten, and the second one was done in Sukabumi. Productivities of seedling transportation using first prototype were about 2,000-3,000 seedling.hm/hour, while the average productivity of improved transportation tool called Semanggi-I equipped with diesel engine was 5,000-6,500 seedlings.hm/ hour. The owning and operating cost for the first tool and Semanggi-I were $\mathrm{Rp} 38.535$ and $\mathrm{R} p$ 42,895/ bour, respectively. The average costs of seedling transportation were Rp 14 for the first tool and $\mathrm{R} p 7$ for the Semanggi-I.
\end{abstract}

Keywords: Forest and land rehabilitation, constraints, transportation, seedling and operation of skyline system.

\begin{abstract}
ABSTRAK
Program nasional gerakan rehabilitasi hutan dan lahan bertujuan untuk memulihkan kembali hutan dan lahan yang terdegradasi. Transportasi bibit pada areal hutan yang bertopografi sulit menghadapi permasalahan dalam angkutan bibit. Antisipasi untuk itu sangat diperlukan agar bibit yang ditanam tetap berkualitas baik dan sehat.

Penelitian ini dilakukan dengan tujuan menghasilkan alat yang efektif dan efisien untuk dipakai dalam membantu angkutan bibit pada areal hutan yang bertopografi sulit. Uji coba rekayasa pertama dilakukan di Carita, Banten, sedangkan uji oba rekayasa kedua dilakukan di Nyalindung, Sukabumi. Produktivitas angkutan bibit dengan alat rekayasa pertama sekitar 2.000-3.000 bibit.hm/jam, sedangkan rata-rata produktivitas rekayasa kedua yang disebut Semanggi-I adalah $6.500 \mathrm{bibit} . \mathrm{hm} / \mathrm{jam}$. Biaya pengangkutan bibit dengan alat prototipe pertama dan alat Semanggi-I masing-masing sebesar Rp 38.535/jam, dan Rp 42.895/jam. Biaya pengangkutan bibit rata-rata adalah Rp 14/batang.hm untuk alat rekayasa pertama dan Rp 7/batang.hm untuk alat Semanggi-I.
\end{abstract}

Kata kunci: Gerhan, kendala, angkutan, bibit, sistem kabel layang. 


\section{PENDAHULUAN}

Pengangkutan bibit untuk rehabilitasi kawasan hutan maupun lahan hutan rakyat, menghadapi permasalahan di areal yang bertopografi berat antara lain: 1) Lokasi tanam umumnya tidak bisa ditempuh dengan kendaraan roda dua apalagi roda empat, karena jalan yang tersedia berupa jalan setapak atau pematang sawah yang sangat licin terutama pada saat musim hujan; 2) Kondisi jalan setapak berlereng tajam serta berkelak kelok, sehingga waktu tempuh dari tempat pengumpulan bibit sementara ke lahan penanaman cukup lama, tenaga kerja cepat lelah dan haus terutama pada musim panas; dan 3) Untuk mencapai lokasi tanaman umumnya melewati lembah atau sungai dan tidak tersedia jembatan penyeberangan, sehingga dapat berisiko tinggi bagi keselamatan pembawa bibit maupun bibit itu sendiri.

Untuk mengatasi masalah tersebut perlu dukungan ketersediaan teknologi inovatif yang tepat guna, murah serta mudah diaplikasikan. Keperluan ini semakin bertambah besar seiring dengan tingginya tuntutan upaya percepatan pembangunan khususnya untuk mengantisipasi masalah lingkungan yang kian memprihatinkan (kekeringan, banjir, longsor, dan isu pemanasan iklim global).

Selain ketiga faktor di atas, pada hutan atau lahan yang terdegradasi umumnya tidak banyak tersedia pohon-pohon besar yang dapat dipakai untuk tempat mengikatkan kabel (spar tree). Untuk itu ketiadaan pohon dicoba diantisipasi dengan merancang bangunan tiang buatan.

Sehubungan dengan hal tersebut di atas, maka dilakukan penelitian penggunaan tiang buatan untuk dapat memberikan kemudahan dan membantu dalam percepatan pengangkutan bibit berkualitas di wilayah yang bertopgrafi berat. Selain itu juga penelitian ini dimaksudkan untuk menguji kembali kinerja alat angkut bibit Semanggi-I yang telah diperbaiki di mana pada tahun sebelumnya diketahui memiliki beberapa kelemahan antara lain pada dudukan drum, roda, kemudi, katrol, sistem pengunci dan kereta pembawa muatan bibit (carriage). Diharapkan dari hasil uji coba perbaikan alat angkut bibit sistem kabel layang Semanggi-I dapat meningkatkan kinerja pengangkutan bibit di areal yang bertopografi berat dan dapat mengatasi kendala lapangan yang sulit.

\section{METODOLOGI PENELITIAN}

\section{A. Lokasi Penelitian}

Uji coba dilakukan di wilayah RPH Buniayu yang terletak di lereng Gunung Kunci, BKPH Cikawung, KPH Sukabumi, berjarak sekitar $25 \mathrm{~km}$ dari kota Sukabumi. Penelitian dilakukan pada akhir bulan Nopember 2006 dan pada saat itu sudah mulai ada turun hujan.

\section{B. Bahan dan Alat}

Bahan penelitian berupa bibit pinus (Pinus merkusii) dan mahoni (Swietenia microphylla) dalam polibeg. Bibit ini berumur antara 0,5 - 1 tahun dan pertumbuhannya cukup baik dengan tinggi bibit antara $30-60 \mathrm{~cm}$. Bibit yang diangkut dalam uji coba ini berjumlah 6.000 batang terdiri dari 5.000 batang bibit pinus dan 1.000 batang bibit mahoni sebagai pencampur. 
Peralatan yang digunakan terdiri dari katrol, satu unit alat angkut bibit sistem rantang, mesin Semanggi-I, tiang (tower) buatan, kabel, satu unit peralatan kunci, bahan bakar solar, bensin, peralatan tulis menulis serta alat pengukur waktu (stop watch).

\section{Prosedur Kerja}

Kegiatan yang dilakukan meliputi:

1. Penyusunan rencana perbaikan alat angkut yaitu pada bagian dudukan as untuk drum kabel tanpa ujung, kabel angkat dan pergerakan roda, agar semua bagian alat yang berputar selalu pada posisi yang normal. Selain itu perbaikan dilakukan pula pada sistem rem dari ketiga alat yang berputar tersebut.

2. Merekayasa tiang buatan untuk tempat kabel utama. Tiang terdiri dari dua bagian yaitu bagian kotak berukuran $60 \mathrm{~cm} \times 70 \mathrm{~cm}$ x $80 \mathrm{~cm}$ yang terdapat di dalam tanah dan berfungsi sebagai landasan dan tiang itu sendiri yang akan dipasang pada landasan dengan sistem baud.

3. Membuat katrol khusus untuk tempat jalannya perputaran kabel tanpa ujung

4. Melakukan survei lokasi uji coba

5. Pemasangan jaringan kabel dan tiang untuk uji coba

6. Pelaksanaan uji coba. Data yang dikumpulkan meliputi jenis dan ukuran bibit (diameter dan tinggi bibit), jarak (meter), waktu pemuatan (menit), pembongkaran (menit) dan penarikan (menit) serta kelebihan maupun kelemahan alat dan dampaknya pada lingkungan.

\section{Analisis Data}

1. Menghitung produktivitas pengangkutan bibit $\left(\mathrm{P}_{\mathrm{AB})}\right.$ dihitung dengan rumus:

$$
\mathrm{P}_{\mathrm{AB}}=\frac{\mathrm{V} \times \mathrm{J}}{\mathrm{W}}
$$

di mana $\mathrm{P}_{\mathrm{AB}}=$ Produktivitas angkutan ( polibeg.hm/jam ); V = Volume muat kotak bibit (isi 100 kantong); W = Waktu kerja efektif (jam) dan $\mathrm{J}=$ Jarak angkut (hm).

2. Analisa biaya mengikuti (Anonim,1974)

a. Biaya penyusutan (Bp)

$$
B p=\frac{M-R}{N \times T}
$$

di mana $\mathrm{Bp}=$ penyusutan $(\mathrm{Rp} / \mathrm{jam}) ; \mathrm{M}=$ investasi alat $(\mathrm{Rp}) ; \mathrm{R}=$ nilai alat bekas $(10 \%$ dari harga baru); $\mathrm{N}=$ umur pakai alat (tahun) dan $\mathrm{T}=$ waktu kerja alat (jam/tahun) 
b. Bunga modal $(\mathrm{Bm})$

$$
\mathrm{Bm}=\frac{\frac{\{(\mathrm{M}-\mathrm{R})(\mathrm{N}+1)+\mathrm{R}\} \times 0,0 \mathrm{p}}{2}}{\mathrm{t}}
$$

di mana $\mathrm{B}=$ bunga modal $(\mathrm{Rp} / \mathrm{jam}) ; \mathrm{p}=$ suku bunga per tahun $(\%$ per tahun $)$ dan $\mathrm{t}=$ waktu kerja (tahun)

c. Biaya perawatan $(\mathrm{Bpr})$

$$
\mathrm{Bpr}=\frac{\text { Harga alat }(\mathrm{Rp}) \times 0,1}{1000 \mathrm{jam}}
$$

d. Biaya bahan bakar $(\mathrm{Bb})$

$$
\mathrm{Bb}=\text { Penggunaan }(\mathrm{lt} / \mathrm{jam}) \mathrm{x} \text { harga bahan bakar per liter }(\mathrm{Rp} / \mathrm{lt})
$$

e. Biaya oli dan pelumas (Bo)

$$
\text { Bo }(\mathrm{Rp} / \mathrm{jam})=\frac{\text { Harga alat }(\mathrm{Rp}) \times 0,005}{1000 \mathrm{jam}}
$$

f. Biaya operator $(\mathrm{Rp} / \mathrm{jam})=$

$$
\text { Gaji (Rp/bulan) }
$$

$$
\text { (20 harix } 8 \mathrm{jam} / \text { hari)/bulan. }
$$

g. Biaya tenaga pembantu $(\mathrm{Btp})(\mathrm{Rp} / \mathrm{jam})=\frac{\mathrm{Rp} 15.000 / \text { hari }}{8 \mathrm{jam} / \mathrm{hari}}$

h. $\quad \operatorname{Pajak}(\mathrm{Pi})=\frac{\text { Harga alat }(\mathrm{Rp}) \times 0,6 \times 2 \%}{1000 \mathrm{jam}}$

i. $\quad$ Asuransi $($ As $)=\frac{\text { Harga alat } \times 0,6 \times 3 \%}{1000 \mathrm{jam}}$

j. Upah pengambilan air

$$
\text { Bair }=\frac{\text { Penggunaan }(4 \mathrm{lt}) / \text { jam }}{\operatorname{Jerigen}(20 \mathrm{lt})} \times \mathrm{Rp} 1.000 / \text { jeriken }
$$


k. Biaya operasi pengiriman bibit $(\mathrm{Bpb})$

$$
B p b=\frac{B p+B m+B r m+B b m+B o+B o p+B t p}{P K}
$$

di mana $\mathrm{Bpb}=$ biaya pengiriman bibit $(\mathrm{Rp} / \mathrm{bibit})$; $\mathrm{Bpm}=$ biaya penyusutan alat muat bongkar (Rp/jam); Bm = biaya modal alat $(\mathrm{Rp} / \mathrm{jam}) ; \mathrm{Brm}=$ biaya perawatan alat $(\mathrm{Rp} / \mathrm{jam}) ; \mathrm{Bbm}=$ biaya bahan bakar (solar) $(\mathrm{Rp} / \mathrm{jam}) ;$ Bo = biaya oli $(\mathrm{Rp} / \mathrm{jam})$; Bop $=$ biaya operator $(\mathrm{Rp} / \mathrm{jam}), \mathrm{Btp}=$ biaya tenaga pembantu $(\mathrm{Rp} / \mathrm{jam})$, biaya pengambilan air $(\mathrm{Rp} / \mathrm{jam})$ dan $\mathrm{PK}=$ produktivitas kerja (batang/jam).

Selain itu dicoba dianalisis nilai IRR dan NPV serta dikaji kelemahan atau kekurangan dari sistem ini.

$$
\left.\mathrm{IRR}=\mathrm{D}_{\mathrm{f}} \mathrm{P}+\left\{\frac{(\mathrm{NPV})}{(\mathrm{PVP})-(\mathrm{PVN})}\right\} \mathrm{x}\left(\mathrm{D}_{\mathrm{f}} \mathrm{N}-\mathrm{D}_{\mathrm{f}} \mathrm{P}\right)\right\}
$$

dimana: $\mathrm{D}_{\mathrm{f}} \mathrm{P}=$ discounting factoryang menghasilkan present value positif

$\mathrm{D}_{\mathrm{f}} \mathrm{N}=$ discounting factoryang menghasilkan present value negatif

PVP $=$ present value positif

$\mathrm{PVN}=$ present value negatif dan

$N P V=\sum_{t=1}^{t=n}\left[\begin{array}{c}b_{t}-c_{t} \\ -(1+i)^{t}\end{array}\right]-K_{0}$

di mana $:$ NPV $=$ nilai bersih sekarang, $K_{0}=$ modal awal $; \mathrm{b}=$ pendapatan; $\mathrm{c}=$ biaya pengeluaran; $\mathrm{I}=$ tingkat suku bunga, dipakai sebagai $\mathrm{D}_{\mathrm{f}}$ (discounting factor) dan $\mathrm{t}=$ tahun (economic life)

\section{HASIL DAN PEMBAHASAN}

\section{A. Persiapan Uji Coba Lapangan}

Lokasi uji coba berada pada jarak sekitar $250 \mathrm{~m}$ dari ujung jalan roda empat ke perkampungan, sedangkan lokasi bukit yang akan ditanami kembali adalah hutan bekas kegiatan tebangan habis tahun 2005 seluas \pm 6 ha. Agar dalam uji coba tidak banyak melakukan pembebasan tanaman buah-buahan dan pisang milik penduduk, maka penempatan tiang buatan dipilih di lokasi yang (a) memungkinkan dapat dipasang dengan bentangan kabel maksimum panjang $450 \mathrm{~m}$, (b) tersedia ruang untuk tempat penyimpanan bibit sebelum diangkut, (c) pemandangan selama kegiatan berjalan cukup jelas dan (d) lapangan tempat penyimpanan bibit relatif datar.

Dengan pertimbangan di atas, maka dari $50 \mathrm{~m}$ sisa panjang kabel pada gulungan drum digunakan untuk penguat ikatan tiang guna mengimbangi beban kabel yang cukup panjang. 
Namun karena dari salah satu kabel utama kurang memadai panjangnya, terpaksa disambung dengan cara diklem (dijepit).

Setelah diadakan pendekatan pada masyarakat, satu tiang buatan dipasang di petak sawah milik penduduk yang saat itu mengering, sedang satu tiang lainnya di tempatkan di pertengahan lereng Gunung Kunci yang akan ditanami kembali dengan tanaman jenis pinus dan mahoni.

Adapun jenis penggunaan lahan yang ada di sekitar daerah uji coba terdiri dari pemukiman, pesawahan dan kebun dengan akses berupa jalan tanah/berbatu selebar satu meteran dan jalan pematang sawah yang licin karena sudah mulai turun hujan.

\section{B. Peran Tiang Pengikat Kabel Buatan}

Tiang buatan untuk tempat kabel utama dibentang dan digunakan sebagai gantungan kereta yang membawa kotak berisi bibit maupun kosong, sangat besar artinya terutama pada lahan yang akan direhabilitasi dan tidak terdapat lagi pohon untuk tempat kabel akan diikatkan. Pada uji coba tahun sebelumnya, di lokasi masih tersedia cukup pohon sehingga dapat dipilih untuk dijadikan tiang ikat. Sedang pada penelitian tahun 2005 , karena tidak ada pohon maka digunakan tiang buatan (Lampiran 3). Keunggulan maupun kelemahan tiang buatan dibanding pohon sebagai tiang ikat (spartree) disajikan pada Tabel 1.

\section{Tabel1. Keunggulan dan kelemahan penggunaan tiang buatan dibanding pohon} Table 1. Advantages and disadvantages of artificial tower compare to span tree

\begin{tabular}{|c|c|c|c|c|}
\hline \multirow[t]{2}{*}{ No } & \multicolumn{2}{|c|}{$\begin{array}{c}\text { Pohon sebagai tiang } \\
\text { (Tree as spar tree) }\end{array}$} & \multicolumn{2}{|c|}{$\begin{array}{l}\text { Tiang buatan } \\
\text { (Artificial tower) }\end{array}$} \\
\hline & $\begin{array}{l}\text { Keunggulan } \\
\text { (Advantages) }\end{array}$ & $\begin{array}{l}\text { Kelemahan } \\
\text { (disadvantages) }\end{array}$ & $\begin{array}{l}\text { Kelebihan } \\
\text { (Advantages) }\end{array}$ & $\begin{array}{l}\text { Kelemahan } \\
\text { (disadvantages) }\end{array}$ \\
\hline 1 & $\begin{array}{l}\text { Tak perlu dibawa } \\
\text { bawa (Not necessary to } \\
\text { be brought) }\end{array}$ & $\begin{array}{l}\text { Posisi sulit / sering tidak } \\
\text { ideal (The position } m \text { ay often } \\
\text { not ideal) }\end{array}$ & $\begin{array}{l}\text { Posisi efektif } \\
\text { (Effective position) }\end{array}$ & $\begin{array}{l}\text { Harus dibawa bila di } \\
\text { lapangan tak tersedia } \\
\text { pohon (Have to be } \\
\text { brought if no available } \\
\text { tree in the field) }\end{array}$ \\
\hline 2 & $\begin{array}{lr}\text { Tak perlu ada } \\
\text { penggalian } \\
\text { necessary to dug soil) }\end{array}$ & $\begin{array}{l}\text { Kesehatan pohon masih } \\
\text { bisa diragukan (The tree } \\
\text { bealty condition may doubt) }\end{array}$ & $\begin{array}{l}\text { Kekuatan lebih terukur } \\
\text { (The power more measurable) }\end{array}$ & $\begin{array}{l}\text { Perlu penggalian } \\
\text { tanah untuk penguat } \\
\text { tiang (Have to dug out } \\
\text { the soil) }\end{array}$ \\
\hline 3 & $\begin{array}{l}\text { Pemasangan kabel bisa } \\
\text { di pasang cukup tinggi } \\
\text { (Setting the cable may } \\
\text { allowed bigher) }\end{array}$ & $\begin{array}{l}\text { Sulit dan dalam } \\
\text { penggunaannya dapat } \\
\text { menyulitkan karena perlu } \\
\text { membuat panggung } \\
\text { (Difficult and in application } \\
\text { more work that should bave to } \\
\text { prepare) }\end{array}$ & $\begin{array}{l}\text { Bisa dijangkau } \\
\text { dioperasikan dengan } \\
\text { mudah ( Easy to gets and } \\
\text { operates) }\end{array}$ & \\
\hline 4 & & $\begin{array}{l}\text { Perlu banyak katrol dan } \\
\text { penggunaan kabel le bih } \\
\text { panjang (Need a lot of pulley } \\
\text { and longer cable) }\end{array}$ & $\begin{array}{l}\text { Tidak perlu banyak katrol } \\
\text { dan penggunaan kabel } \\
\text { lebih pendek ( Need a fenv } \\
\text { pulley and shorter cable) }\end{array}$ & \\
\hline
\end{tabular}


Dari Tabel 1 dapat dilihat bahwa pohon dan tiang buatan, masing-masing memiliki kelebihan maupun kelemahan, akan tetapi mengingat kenyataan di areal hutan dan lahan yang terdegradasi sulit untuk mendapatkan pohon untuk tempat mengikatkan kabel, maka peran tiang buatan sangat penting. Tiang buatan ini beratnya tidak lebih dari $50 \mathrm{~kg}$, sehingga relatif mudah dipikul untuk dibawa ke tempat yang dituju. Sedangkan dampaknya terhadap lingkungan yang terkait dengan erosi sangat kecil yakni sebatas penghanyutan tanah yang berada di sekitar pembuatan lubang, sementara tanah yang digali berada dalam karung. Selain itu tidak banyak terjadi pemadatan tanah karena pengangkutan bibit dilakukan melalui udara.

\section{Kinerja Mesin Angkut Bibit}

Bibit yang akan ditanam diambil dari persemaian Buniayu yang berjarak $\pm 7 \mathrm{~km}$ dari lokasi uji coba. Bibit yang diambil dari persemaian tersebut disimpan pada kotak dan diangkut menggunakan mobil Taft yang mampu mengangkut \pm 600 polybag per rit. Bibit ini kemudian dikumpulkan sementara di sebuah kebun yang terletak di seberang Gunung Kunci. Dari tempat ini bibit dipikul ke tempat di mana sistem kabel layang dioperasikan. Pada setiap kotak, dapat diisi 150 polybag untuk cara penyimpanan dua susun dan sekitar 100 polybag untuk cara penyimpanan satu susun. Bibit yang disimpan dalam kotak lalu dikirim ke lokasi penanaman menggunakan kereta angkut dengan cara digantung pada kabel utama dan kemudian dikunci pada kabel endless.

Pada uji coba ini, dipasang dua jalur kabel utama. Jalur kabel pertama berfungsi sebagai tempat menggantung kotak berisi muatan bibit, dan jalur kabel kedua untuk pengembalian kotak kosong. Dengan cara itu, pada saat bersamaan ada kotak berisi bibit sampai di tujuan, sementara di jalur kabel lain ada kotak bibit kosong sampai di tempat pengisian, sehingga pengangkutan bibit dapat dilakukan dengan cepat. Dengan adanya letak kabel utama cukup berdekatan, maka petugas lapangan tidak banyak mengalami kesulitan untuk melakukan muat bongkar kotak bibit, yang biasanya ini menjadi kendala besar pada operasi kabel layang. Hasil pengamatan pengangkutan bibit dengan menggunakan sistem kabel layang disajikan pada Tabel 2 dan hasil selengkapnya dapat dilihat pada Lampiran 1.

\section{Tabe12. Pengangkutan bibit dengan menggunakan kabellayang}

Table 2. Transportation of seedling using skyline

\begin{tabular}{|c|l|c|c|}
\hline No & \multicolumn{1}{|c|}{ Uraian (Explanation) } & Unit & Nilai (Value) \\
\hline 1 & Kisaran (Range) & Batang (Piece) & $5.145-8.273$ \\
\hline 2 & Rata-rata (Mean) & Batang (Piece) & 6.292 \\
\hline 3 & $\mathrm{~S}_{\mathrm{d}}$ (Standard deviation) & Batang (Piece) & 659.435 \\
\hline 4 & $\mathrm{CV}$ (Coefficient variation) & $\%$ & 10,5 \\
\hline
\end{tabular}

Uji coba pengangkutan bibit pinus $43 \mathrm{kali}$ dengan tinggi bibit sekitar $20 \mathrm{~cm}$ dan 16 kali uji coba pengangutan bibit mahoni dengan tinggi bibit antara $45-65 \mathrm{~cm}$, diketahui bahwa waktu pengangkutan bibit rata-rata 8,25 menit, terdiri dari 1,11 menit untuk mengisi dan memasang kotak pada kereta angkut kabel layang (carriage), 6 menit untuk perjalanan angkutan serta 1,10 menit untuk bongkar kotak dan penurunan bibit dari kotak. 
Informasi dari masyarakat menunjukan bahwa untuk mengangkut bibit sebanyak 40100 batang pada lahan berbukit dengan jalan setapak naik turun sejauh $200 \mathrm{~m}$, diperlukan waktu sekitar 20-30 menit. Pada medan yang berlereng lebih curam, dan jalan licin, diperlukan waktu lebih lama dan kemampuan pengangkutan bibit menjadi lebih sedikit. Oleh karena itu untuk daerah-daerah yang bertopografi sulit diperlukan dukungan teknologi, di antaranya penggunaan teknologi kabel layang. Dengan sepeda motor atau mobil, tanpa prasarana memadai pengangkutan bibit ke lokasi tanam tidak akan efektif.

Dari data seperti tersaji pada Lampiran 1 terlihat bahwa produktivitas pengangkutan bibit rata-rata 6.292 bibit.hm/jam. Jumlah ini lebih tinggi dibanding hasil uji coba tahun sebelumnya yang produkivitasnya hanya mencapai 2.778 batang/jam. Kemampuan mengangkut bibit dapat ditingkatkan apabila kotak bibit tersedia lebih banyak, maka jumlah bibit yang dapat diangkut tentu jauh lebih banyak lagi. Memperhatikan hasil yang diperoleh, ternyata pemakaian tiang buatan sangat membantu kelancaran pengangkutan bibit karena pengangkutan bibit menjadi lebih cepat dan lebih efektif dibanding cara manual ataupun penggunaan kabel konvensional yang mempegunakan sistem kabel layang satu jalur.

Mengingat animo masyarakat untuk melakukan penanaman pohon semakin besar (Djayapertjunda, 2003), maka peran penyediaan dan pengangkutan bibit sampai di lokasi penanaman, terutama pada wilayah yang topografinya sulit dan cukup luas menjadi penting, karena keberhasilan penanaman bibit dapat meningkatkan kehidupan ekonomi, membantu menjaga keseimbangan tata air, mengurangi banjir dan mempro-duksi oksigen.

Di sisi lain, dengan dukungan kreativitas penggunaan teknologi yang sesuai dan efisien, diharapkan kemampuan penanaman bibit yang berkualitas meningkat, sehingga antisipasi upaya pemulihan lahan-lahan kritis menjadi lebih cepat, utamanya pada lahan-lahan yang medannya berat. Dukungan kreativitas dalam penanganan bibit yang diperlukan tersebut mencakup beberapa aspek teknis yaitu aman saat pengangkutan, mudah dilakukan, ringan, mutu bibit terjaga, alat cukup tahan lama serta mudah dibangun oleh masyarakat dan harga relatif murah (Djapilus, 1988).

Dengan tersedianya sistem kabel layang ini, kesulitan di lapangan seperti melewati sungai, lembah, persawahan atau kebun dapat diantisipasi; namun konsekwensinya memerlukan waktu khusus untuk memasang kabel antara 1-3 hari, tergantung tingkat kesulitan dan fasilitas yang tersedia seperti panjang kabel, jenis dan jumlah katrol, ukuran dan kondisi tirfor untuk alat bantu pengencang kabel, keberadaan pohon untuk pemasangan kabel utama maupun kabel pembantu (baul back) dan tenaga kerja yang terampil. Namun demikian, hilangnya waktu yang diperlukan untuk pemasangan kabel terkompensasi oleh kecepatan pengiriman bibit setelah jaringan kabel selesai dilakukan dan terpasang dengan baik.

\section{Penggunaan Bahan Bakar}

Bahan bakar yang digunakan untuk operasi pengiriman bibit sistem kabel layang berupa solar dengan harga di lokasi setempat sebesar Rp 5.000,- per liter. Kapasitas tangki diesel merk Changchai yang berukuran $20 \mathrm{~cm} \times 20 \mathrm{~cm} \times 15 \mathrm{~cm}$ atau sebanyak 6 liter.

Berdasarkan hasil uji coba tahun 2005 (Endom, 2006), penggunaan solar untuk pemakaian selama 367 menit pada tangki terukur setinggi $6,55 \mathrm{~cm}$. Volume solar dalam tangki untuk setiap $1 \mathrm{~cm}$ adalah $6 \mathrm{lt} / 15 \mathrm{~cm}=0,4 \mathrm{lt} / \mathrm{cm}$. Dengan demikian pemakaian solar 
selama kegiatan uji coba ialah sebanyak $6,55 \times 0,4 \times 1$ lt $=2,62$ lt untuk selama waktu 6 jam. Berarti solar yang digunakan sekitar $0,44 \mathrm{lt} / \mathrm{jam}$.

Pada uji coba tahun 2006, pemakaian bahan bakar selama kegiatan 5 jam adalah setebal $5,5 \mathrm{~cm}$. Dengan demikian volume bahan bakar yang terpakai adalah $5,5 \times 0,4 \mathrm{lt}=$ 2, 42 liter atau 0,4 liter/jam, yang bila diuangkan setara dengan Rp 2500 untuk setiap operasi pengiriman bibit untuk selama waktu satu jam. Perlu diketahui bahwa penggunaan mesin diesel memerlukan air pendingin cukup banyak yakni hampir mencapai 3-4 liter/jam. Bila mesin bekerja selama 8 jam berarti air yang diperlukan sebanyak 30-32 liter atau 2 jeriken isi 20 liter. Sekalipun air mudah diperoleh, namun diperlukan upah untuk mengambilnya dengan biaya Rp 1.000 per sekali pengambilan. Dengan demikian akan selalu tersedia air cukup untuk pengisian air pendingin mesin.

\section{E. Analisa Biaya}

Untuk pengadaan mesin dan pembuatan seperangkat alat sistem kabel layang model Semanggi - I, diperlukan biaya sebesar Rp 25 juta. Ditambah dengan kabel utama dua gulung masing-masing 350 meter, kabel endless 750 meter, dua buah Tirfor, kabel pembantu berikut katrol (pulley), sakel, klem dan dua buah tiang buatan seluruhnya bernilai Rp 15 juta; berarti satu unit alat angkut bibit sistem kabel layang perlu investasi sebesar Rp 40 juta. Atas dasar perhitungan biaya tersebut maka biaya pengangkutan bibit menggunakan sistem kabel layang seperti disajikan pada Tabel 3 .

\section{Tabel 3. Biaya pengangkutan bibit sistem kabellayang}

\section{Table 3. Seedling transportation cost using skyline system}

\begin{tabular}{|l|l|l|c|}
\hline No & \multicolumn{1}{|c|}{$\begin{array}{c}\text { Kelompok biaya } \\
\text { (Cost category) }\end{array}$} & \multicolumn{1}{|c|}{$\begin{array}{c}\text { Uraian } \\
\text { (Description) }\end{array}$} & $\begin{array}{c}\text { Biaya (Rp/jam/ } \\
\text { Cost (Rp/ hour) }\end{array}$ \\
\hline 1 & Biaya tetap (Fixed cost) & Biaya penyusutan/(Depreciation cost) & 3,600 \\
\hline & & Bunga modal (Interest rate) & 4,320 \\
\hline & & Biaya pajak (Tax) & 720 \\
\hline & Jumlah- 1/(Total-1) & Biaya asuransi (Insurance) & 480 \\
\hline 2 & Biaya tak tetap (Variable cost) & Operator mesin (Macbine operator) & 9,120 \\
\hline & & Upah tenaga pembantu (Labor cost) ${ }^{1)}$ & 9,375 \\
\hline & & Harga bahan bakar (Fuel cost) & 17,500 \\
\hline & & Oli dan pelumas (Oil and grease) & 2,500 \\
\hline & & Biaya perawatan (Maintenance cost) & 200 \\
\hline & & Upah ambil air (water supply wage) & 4,000 \\
\hline & Jumlah - 2(Total -2) & & 200 \\
\hline & Jumlah semua (Grand total) & & 33,775 \\
\hline
\end{tabular}

Keterangan/Remarks: 1) Tenaga pembantu 4 orang (Helper 4 men), 2) Harga bahan bakar setempat Rp 5.000,-per liter (Localprice forfuel Rp 5,000/ltr)

Tabel 3 memperlihatkan biaya pengangkutan bibit sebesar Rp 42.895/jam, dan dalam satu jam rata-rata dapat diangkut bibit sebanyak 6.292 batang. Ini berarti biaya pengangkutan bibit adalah Rp 6,81 dibulatkan menjadi Rp 7/batang. Dengan cara pikul, 
upah angkut untuk sejauh $450 \mathrm{~m}$ sebesar Rp 50/batang. Berarti biaya pengangkutan bibit sistem kabel layang masih lebih murah 7 kali dibanding cara manual. Selain itu cara pikul manual lebih lambat dan risiko rusaknya bibit menjadi lebih besar karena jalan licin saat melewati pematang kecil maupun menaiki jalan setapak.

Memperhatikan besaran rupiah untuk pengangkutan bibit yang cukup murah dan kualitasnya juga cukup baik dibanding cara manual yang risikonya lebih besar; maka rekayasa alat angkut sistem kabel layang dan penggunaan tiang buatan dapat memberikan harapan besar bagi percepatan kegiatan rehabilitasi lahan.

Bila akan dijadikan sebagai suatu usaha, dengan misalnya memberikan sewa alat per batang Rp 10; maka hasil analisis dengan mempergunakan kotak bibit sebanyak 6 buah dan 200 hari kerja setahun maka diperoleh nilai NVP Rp 12.835 .409 dan IRR 32\%. Ini berarti metoda ini cukup layak diusahakan, karena nilai IRR yang diperoleh lebih besar dari bunga bank yaitu $18 \%$ /tahun dan NPV positif.

\section{KESIMPULAN DAN SARAN}

1. Rekayasa tiang buatan sebagai pengganti pohon untuk tempat pengikat bentangan kabel sangat membantu dalam mempercepat dan memudahkan kegiatan pengangkutan bibit dengan sistem kabel layang.

2. Model prototipe Semanggi-I dengan tenaga diesel 6 PK cukup efektif sebagai alat pengangkut bibit

3. Drum endless cukup efektif untuk menarik dan menggulung kabel setelah kegiatan selesai dilakukan.

4. Produktivitas alat Semanggi-I untuk mengangkut bibit dengan sistem kabel layang adalah 6.292 bibit.hm/jam.

5. Biaya pembuatan alat angkut bibit Semanggi-I beserta perlengkapannya sebesar Rp 40 juta/unit, maka biaya pengangkutan bibit sebesar Rp 42.895/jam, yang terdiri dari biaya tetap sebesar Rp 9.120/jam, biaya tidak tetap sebesar Rp 33.775, dan kemampuan pengangkutan bibit 6.292 batang/jam. Berarti, biaya pengangkutan bibit adalah Rp 6,78/batang (dibulatkan menjadi Rp 7). Biaya ini dapat dikatakan cukup murah dibanding cara manual yang mencapai Rp 50/batang.

6. Dengan suku bunga pinjamaan $18 \%$ per tahun dan sewa alat pengangkutan bibit Semanggi-I Rp 10/batang, maka usaha ini dapat dipakai sebagai suatu usaha komersial karena diperoleh NPV positif mencapai Rp 12.835.409,81 dan IRR sebesar 32\%.

\section{DAFTAR PUSTAKA}

Anonim.1974. Logging and log transport in tropical high forest. Food and Agriculture Organization of the United Nations. Rome.

Harahap, H. 1989. Volume produksi HTI lima kali produksi hutan alam. Sambutan tertulis pidato Menteri kehutanan pada pembukaan seminar mahasiswa kehutanan se Indonesia tanggal 12 Oktober 1988 di Yogyakarta. Kehutanan Indonesia No 32. Departemen Kehutanan. Jakarta. 
Djapilus, A. 1988. Bibit akar telanjang pangkasan akar dan prospeknya dalam pembangunan Hutan Tanaman Industri. Duta Rimba No 119-120/XVI. Perhutani. Jakarta.

Djayapertjunda, S. 2003. Hutan rakyat di Jawa Barat. Prosiding Lokakarya Konsepsi Pengelolaan Kawasan Lindung Jawa Barat pada tanggal 27 Agustus 2002 di Hotel Savoy Homan, Bandung. Alqaprint Jatinangor. Sumedang.

Endom, W 2006. Kajian operasi pengeluaran kayu sistem kabel layang Expo-2000 dengan penggunaan alat pendukung. Jurnal Penelitian Hasil Hutan 24 (40): 339-357. Bogor.

, Y.Sugilar dan S Suprapto. 2007. Produktivitas dan biaya pengangkutan bibit pada medan sulit dengan sistem kabel layang. Jurnal Penelitian Hasil Hutan 25 (1) : 1-14. Bogor.

Mulyana, Y. 2002. Naskah akademik konsep kawasan lindung Jawa Barat. Konsep Anggota Forum Peduli Hutan Nusantara, Bogor. Tidak diterbitkan.

Saleh, W. 1990. Melepas diri dari buaian. Duta Rimba No 117-118/XVI. Perhutani. Jakarta. 


\section{Lampiran1. Produktivitas pengangkutan bibit pada sistem kabel layang dengan jarak bentang kabel $450 \mathrm{~m}$}

Appendice1. Productivity of seedling transportation using skyline system of the distance about $450 \mathrm{~m}$

\begin{tabular}{|c|c|c|c|c|c|c|c|c|c|}
\hline \multirow[b]{2}{*}{ No } & \multirow[b]{2}{*}{$\begin{array}{c}\text { Jenis } \\
\text { (Speries) }\end{array}$} & \multirow[b]{2}{*}{$\begin{array}{c}\text { Isi/ } \\
\text { (Number) } \\
(B t / P(s)\end{array}$} & \multirow[b]{2}{*}{$\begin{array}{l}\text { Tinggi } \\
(\text { Height) }\end{array}$} & \multicolumn{4}{|c|}{ Waktu / Tïme } & \multirow[b]{2}{*}{$\begin{array}{c}\text { Jarak } \\
\text { (Distance) } \\
\text { (Meter) }\end{array}$} & \multirow[b]{2}{*}{$\begin{array}{l}\text { Produktivitas } \\
\text { (Productivity) } \\
\text { (Bt.hm/jam) } \\
\text { (pcs.bm/ bour) }\end{array}$} \\
\hline & & & & $\begin{array}{l}\text { Pengisian dan } \\
\text { pemasangan } \\
\text { (Fill and set-up) } \\
\text { (Menit/Minute) }\end{array}$ & $\begin{array}{l}\text { Pengiriman } \\
\text { (Sending) } \\
\text { (Menit/ } \\
\text { Minute) }\end{array}$ & $\begin{array}{l}\text { Bongkar } \\
\text { dan } \\
\text { penurunan } \\
\text { (Loading and } \\
\text { un-loading) } \\
\text { (Menit/ } \\
\text { Minute) } \\
\end{array}$ & $\begin{array}{c}\text { Total } \\
\text { (Menit/ } \\
\text { Minutej) }\end{array}$ & & \\
\hline 1 & Tusam & 100 & 20 & 1.5 & 5.46 & 0.82 & 7.78 & 450 & 5.835 \\
\hline 2 & Tusam & 100 & 20 & 1.3 & 5.44 & 0.94 & 7.68 & 450 & 5.760 \\
\hline 3 & Tusam & 100 & 20 & 0.9 & 5.63 & 0.83 & 7.36 & 450 & 5.520 \\
\hline 4 & Tusam & 100 & 20 & 0.51 & 5.77 & 0.85 & 7.13 & 450 & 5.348 \\
\hline 5 & Tusam & 100 & 20 & 0.53 & 5.6 & 1.25 & 7.38 & 450 & 5.535 \\
\hline 6 & Tusam & 100 & 20 & 0.51 & 5.39 & 0.96 & 6.86 & 450 & 5.145 \\
\hline 7 & Tusam & 100 & 20 & 0.52 & 5.62 & 1.21 & 7.35 & 450 & 5.513 \\
\hline 8 & Tusam & 100 & 20 & 0.48 & 5.53 & 1.14 & 7.15 & 450 & 5.363 \\
\hline 9 & Tusam & 100 & 20 & 0.56 & 6.15 & 1.22 & 7.93 & 450 & 5.948 \\
\hline 10 & Tusam & 100 & 20 & 1.54 & 6.2 & 1.18 & 8.92 & 450 & 6.690 \\
\hline 11 & Tusam & 100 & 20 & 1.54 & 6.15 & 1.12 & 8.81 & 450 & 6.608 \\
\hline 12 & Tusam & 100 & 20 & 1.52 & 6.27 & 0.88 & 8.67 & 450 & 6.503 \\
\hline 13 & Tusam & 100 & 20 & 1.5 & 5.53 & 1.24 & 8.27 & 450 & 6.203 \\
\hline 14 & Tusam & 100 & 20 & 0.74 & 5.47 & 1.22 & 7.43 & 450 & 5.573 \\
\hline 15 & Tusam & 100 & 20 & 1.36 & 6.26 & 1.12 & 8.74 & 450 & 6.555 \\
\hline 16 & Tusam & 100 & 20 & 1.15 & 5.26 & 1.18 & 7.59 & 450 & 5.693 \\
\hline 17 & Tusam & 100 & 20 & 1.18 & 6.35 & 0.98 & 8.51 & 450 & 6.383 \\
\hline 18 & Tusam & 100 & 20 & 0.63 & 6.42 & 0.86 & 7.91 & 450 & 5.933 \\
\hline 19 & Tusam & 100 & 20 & 1.53 & 6.43 & 1.12 & 9.08 & 450 & 6.810 \\
\hline 20 & Tusam & 100 & 20 & 1.2 & 6.52 & 1.14 & 8.86 & 450 & 6.645 \\
\hline 21 & Tusam & 120 & 20 & 1.38 & 7.17 & 1.16 & 9.71 & 450 & 7.283 \\
\hline 22 & Tusam & 120 & 20 & 1.14 & 6.17 & 0.89 & 8.2 & 450 & 6.150 \\
\hline 23 & Tusam & 120 & 20 & 1.12 & 5.33 & 0.94 & 7.39 & 450 & 5.543 \\
\hline 24 & Tusam & 120 & 20 & 1.25 & 6.35 & 0.98 & 8.58 & 450 & 6.435 \\
\hline 25 & Tusam & 120 & 20 & 0.62 & 5.57 & 1.18 & 7.37 & 450 & 5.528 \\
\hline 26 & Tusam & 120 & 20 & 1.52 & 6.19 & 1.08 & 8.79 & 450 & 6.593 \\
\hline 27 & Tusam & 120 & 20 & 1.54 & 5.58 & 1.12 & 8.24 & 450 & 6.180 \\
\hline 28 & Tusam & 120 & 20 & 1.3 & 7.5 & 1.24 & 10.04 & 450 & 7.530 \\
\hline 29 & Tusam & 120 & 20 & 1.17 & 5.59 & 1.29 & 8.05 & 450 & 6.038 \\
\hline 30 & Tusam & 120 & 20 & 1.18 & 4.57 & 1.22 & 6.97 & 450 & 5.228 \\
\hline 31 & Tusam & 100 & 20 & 1.21 & 5.61 & 1.18 & 8 & 450 & 6.000 \\
\hline 32 & Tusam & 120 & 20 & 1.18 & 5.59 & 1.32 & 8.09 & 450 & 6.068 \\
\hline 33 & Tusam & 120 & 20 & 1.16 & 5.54 & 1.2 & 7.9 & 450 & 5.925 \\
\hline 34 & Tusam & 120 & 20 & 1.08 & 5.57 & 1.29 & 7.94 & 450 & 5.955 \\
\hline 35 & Tusam & 120 & 20 & 1.13 & 5.56 & 1.14 & 7.83 & 450 & 5.873 \\
\hline 36 & Tusam & 120 & 20 & 1.12 & 5.57 & 1.16 & 7.85 & 450 & 5.888 \\
\hline 37 & Tusam & 120 & 20 & 1.1 & 5.88 & 1.41 & 8.39 & 450 & 6.293 \\
\hline 38 & Tusam & 120 & 20 & 1.15 & 6.19 & 1.18 & 8.52 & 450 & 6.390 \\
\hline 39 & Tusam & 120 & 20 & 0.82 & 7 & 1.13 & 8.95 & 450 & 6.713 \\
\hline
\end{tabular}


Uji coba dengan menggunakan tiang pembantu dan perbaikan .... (Wesman Endom)

\section{Lanjutan}

\begin{tabular}{|c|c|c|c|c|c|c|c|c|c|}
\hline 40 & Tusam & 120 & 20 & 1.28 & 6.19 & 1.15 & 8.62 & 450 & 6.465 \\
\hline 41 & Tusam & 120 & 20 & 1.11 & 6.28 & 1.18 & 8.57 & 450 & 6.428 \\
\hline 42 & Mahoni & 100 & 45 & 1.44 & 6.28 & 1.12 & 8.84 & 450 & 6.630 \\
\hline 43 & Mahoni & 100 & 45 & 0.64 & 6.29 & 1.22 & 8.15 & 450 & 6.113 \\
\hline 44 & Mahoni & 100 & 45 & 1.62 & 7.85 & 1.26 & 10.73 & 450 & 8.048 \\
\hline 45 & Mahoni & 100 & 45 & 0.67 & 8.71 & 0.92 & 10.3 & 450 & 7.725 \\
\hline 46 & Mahoni & 100 & 45 & 1.34 & 8.75 & 0.94 & 11.03 & 450 & 8.273 \\
\hline 47 & Mahoni & 100 & 55 & 1.24 & 6.18 & 0.96 & 8.38 & 450 & 6.285 \\
\hline 48 & Mahoni & 100 & 65 & 1.15 & 5.88 & 0.88 & 7.91 & 450 & 5.933 \\
\hline 49 & Mahoni & 100 & 50 & 1.35 & 6.19 & 0.96 & 8.5 & 450 & 6.375 \\
\hline 50 & Mahoni & 100 & 45 & 1.12 & 5.9 & 1.16 & 8.18 & 450 & 6.135 \\
\hline 51 & Mahoni & 80 & 45 & 1.44 & 6.3 & 1.08 & 8.82 & 450 & 6.615 \\
\hline 52 & Mahoni & 80 & 55 & 1.28 & 5.85 & 1.12 & 8.25 & 450 & 6.188 \\
\hline 53 & Mahoni & 80 & 65 & 1.16 & 6.35 & 1.14 & 8.65 & 450 & 6.488 \\
\hline 54 & Mahoni & 80 & 65 & 1.15 & 7.35 & 1.13 & 9.63 & 450 & 7.223 \\
\hline 55 & Mahoni & 75 & 55 & 1.32 & 5.54 & 1.18 & 8.04 & 450 & 6.030 \\
\hline 56 & Mahoni & 75 & 55 & 1.1 & 6.15 & 1.22 & 8.47 & 450 & 6.353 \\
\hline 57 & Mahoni & 50 & 60 & 1.16 & 6.21 & 1.24 & 8.61 & 450 & 6.458 \\
\hline 58 & Mahoni & 50 & 55 & 1.14 & 6.82 & 1.32 & 9.28 & 450 & 6.960 \\
\hline \multirow[t]{3}{*}{59} & Mahoni & 30 & 45 & 1.28 & 7.16 & 1.34 & 9.78 & 450 & 7.335 \\
\hline & Total & 6000 & & 66.86 & 362 & 65.89 & 494.96 & & 371.220 \\
\hline & $\begin{array}{l}\text { Rata-rata/ } \\
\text { Average }\end{array}$ & 102 & & 1.11 & 6 & 1.10 & 8.25 & & 6.292 \\
\hline
\end{tabular}

Keterangan (Remarks) : $\mathrm{Bt}=$ Batang (Pieces); Pcs $=$ Pieces 
Lampiran 2. Gambar prototipe Semanggi-I, skala 1: 10 Appendix 2. Prototype of Semanggi $-I$, scale $1: 10$

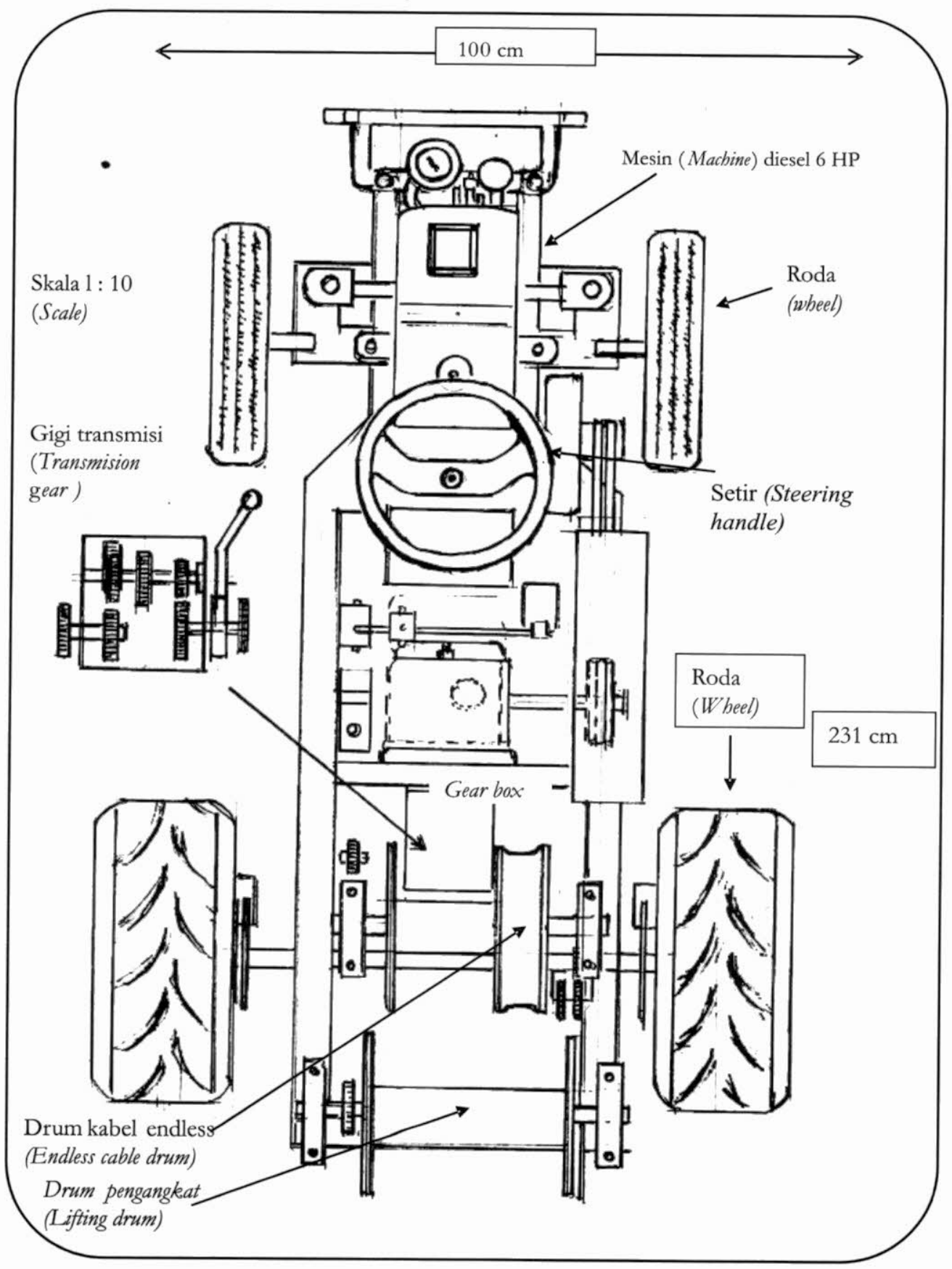


Lampiran 3 Tiang penyangga kabel buatan, alas tiang, kereta dan katrol Appendix 3. Artificial tower, construction base, carriage and pulley

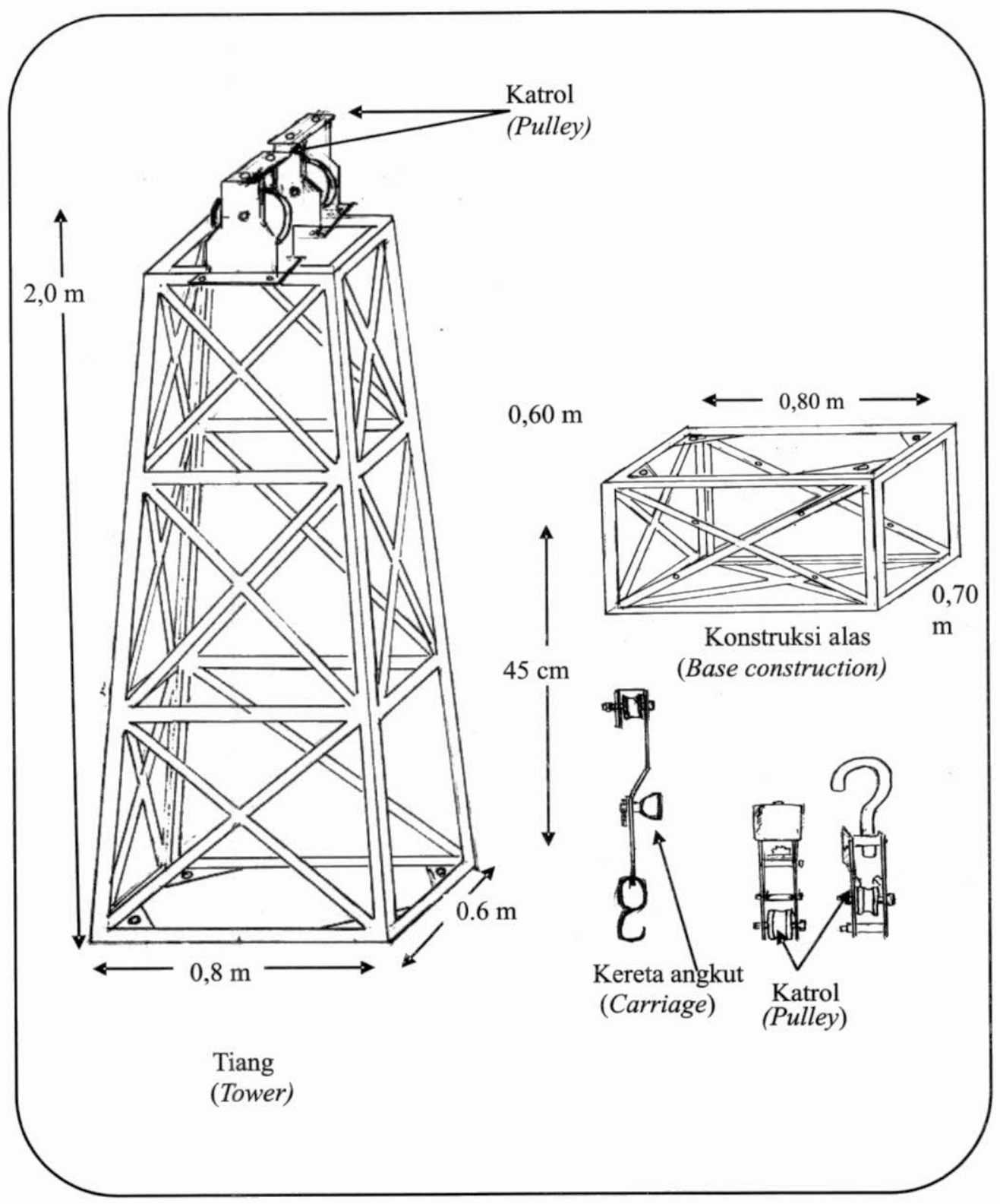

